\title{
UTILIZATION OF BASALT FIBERS AS A RAW MATERIAL FOR CLAY CERAMIC PRODUCTION
}

\author{
SUPAWAN VICHAPHUND, KRITKAEW SOMTON, THASSANEE WONGLOM, \\ MANA RODCHOM, ${ }^{\# D U A N G D U E N ~ A T O N G ~}$ \\ Ceramic Technology Research Unit, National Metal and Materials Technology Center, \\ Pathumthani, 12120, Thailand \\ "E-mail: duangdua@mtec.or.th
}

Submitted September 14, 2015; accepted January 22, 2016

\begin{abstract}
Keywords: Basalt fiber, Clay-based ceramics, Density, Strength, Stoneware tile
This research aimed to investigate the possibility of utilization basalt fibers as a raw material for ceramic production. Both quartz and feldspar were replaced partially or entirely by basalt fiber in the range of $10-25 \mathrm{wt} . \%$. The mixture of ceramic powders and basalt fibers were uniaxially pressed and sintered at temperatures between 1000 and $1200^{\circ} \mathrm{C}$ for $1 \mathrm{~h}$. The substitution of basalt fibers in ceramic compositions demonstrated the positive effect on the physical and mechanical properties. The addition of basalt fibers in an appropriate amount enhanced the densification and reduced sintering temperature of clay-based ceramics (CB-0) from 1200 to $1150^{\circ} \mathrm{C}$. The highest density and strength were $2.40 \mathrm{~g} \cdot \mathrm{cm}^{-3}$ and $116 \mathrm{MPa}$, respectively, when replacing feldspar and quartz with basalt up to $20 \mathrm{wt} \%(\mathrm{CB}-20)$ and sintering at $1150^{\circ} \mathrm{C}$.
\end{abstract}

\section{INTRODUCTION}

Stoneware, a dense ceramic material, is commonly used for manufacturing floor and wall tiles. The characteristics of stoneware sintered products are low water absorption ( $<0.5 \%$ according to ISO 13006) with good physical and mechanical properties such as high hardness, abrasion resistance, and bending strength. Stoneware body ordinarily consists of a mixture of the main components including kaolin, ball clay, feldspar and quartz. Typically, stoneware compositions contain 30 - $40 \%$ plastic components (kaolin and clay), 45-55\% fluxing agent (feldspar), and 5 - $20 \%$ grog (quartz) [1-2]. Many researchers have studied alternative materials such as granite wastes, fly ash, pyrophyllite, and basalt rock for replacing clay-based ceramic components [3-8].

Also wollastonite, a CaO-rich mineral with needleshaped crystals, has been used in ceramic production, including stoneware. In this context wollastonite acts as a fiber-reinforcement similar as in fiber composites. It improves the strength of ceramic green bodies and offers low firing temperature due to fluxing characteristics [9-11]. From this point of view, it is worthwhile investigating the idea of using another fiber material, basalt fiber, as an alternative raw material for clay-based ceramics. So far, however, there are only a few reports focusing on the application of basalt fibers in ceramic production [12]. Basalt fiber is an inorganic fiber extruded from melted basalt rock. The production of this fiber is similar to glass fiber, but it requires less energy and no additives, causing the low cost of production compared to glass or carbon fibers [12-13]. Generally, the main components of basalt are $\mathrm{SiO}_{2}$ and $\mathrm{Al}_{2} \mathrm{O}_{3}$, with minor constituents including $\mathrm{Fe}_{2} \mathrm{O}_{3}, \mathrm{CaO}, \mathrm{MgO}, \mathrm{Na}_{2} \mathrm{O}$, $\mathrm{TiO}_{2}$, and $\mathrm{K}_{2} \mathrm{O}$ [14]. That means from the viewpoint of its chemical composition, basalt fiber contains several oxides found also in ceramic raw materials.

In this work, basalt fibers are used for replacing some ceramic components such as quartz and potash feldspar in amounts of $10-25$ wt. \%. The mixtures are sintered at various temperatures between 1000 and $1200^{\circ} \mathrm{C}$. The effect of basalt substitution on the physical and mechanical properties of the ceramics is discussed.

\section{EXPERIMENTAL}

Commercial clays, including kaolin (Amarin Ceramics Co., Ltd, Thailand) and ball clay (Compound Clay Co., Ltd, Thailand), potassium feldspar (Amarin Ceramics Co., Ltd, Thailand), and quartz (Cernic International Co., Ltd, Thailand) were used as raw materials for ceramic production. Basalt fiber used as an additional raw material came from a local basalt plant from Thailand (Siamfrit Co., Ltd, Thailand) (Figure 1). The chemical composition of these raw materials was analyzed by X-ray fluorescence (XRF). The ceramic compositions were prepared by mixing $50 \%$ clay $(25 \%$ kaolin and $25 \%$ ball clay), $25 \%$ quartz and $25 \%$ potassium feldspar. Both quartz and feldspar were replaced by basalt fiber in different amounts as shown in Table 1. 


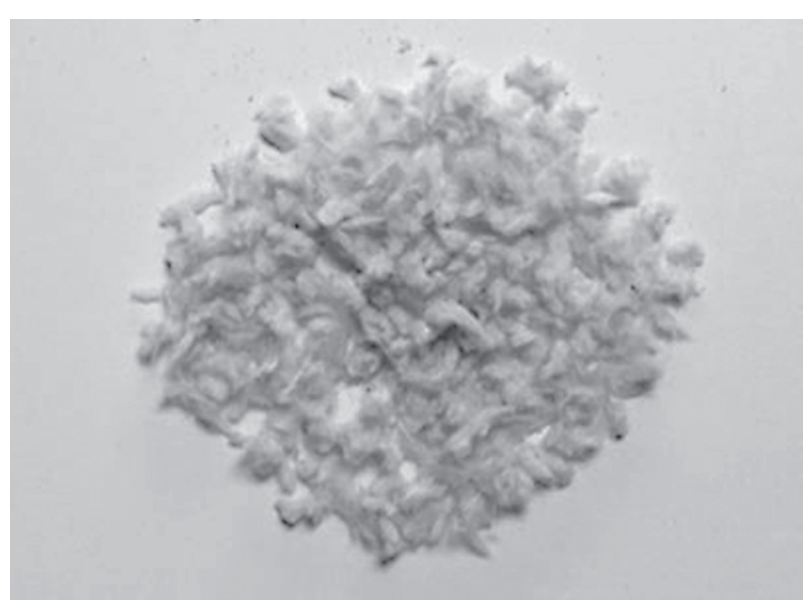

Figure 1. Chopped basalt fibers.

The powders were mixed in proper amounts by conventional ball milling with water for $24 \mathrm{~h}$ using alumina milling media. After milling, the slurry was dried at $100^{\circ} \mathrm{C}$. The mixed powder then passed through a 100 -mesh screen and, was uniaxially pressed at $31 \mathrm{MPa}$ to form a bar-shaped specimen $(3 \times 4 \times 30 \mathrm{~mm})$. The green density of specimens was in the range of $1.5-1.6 \mathrm{~g} \cdot \mathrm{cm}^{-3}$. The samples were sintered in an electric furnace at five different temperatures (1000, 1050, 1100,1150 , and $1200^{\circ} \mathrm{C}$ ) for $1 \mathrm{~h}$ with a heating rate of $5^{\circ} \mathrm{C} \cdot \mathrm{min}^{-1}$. The density and porosity of sintered samples were determined using the Archimedes method. The linear shrinkage was measured by dimension calculation.

Table 1. Sample compositions.

\begin{tabular}{lccccc}
\hline \multirow{2}{*}{ Composition } & \multicolumn{5}{c}{ Raw materials (wt. \%) } \\
\cline { 2 - 6 } & Kaolin & Ball clay & Quartz & K-feldspar & Basalt \\
\hline CB-0 & 25 & 25 & 25 & 25 & 0 \\
CB-F25 & 25 & 25 & 25 & 0 & 25 \\
CB-Q25 & 25 & 25 & 0 & 25 & 25 \\
CB-10 & 25 & 25 & 20 & 20 & 10 \\
CB-20 & 25 & 25 & 15 & 15 & 20 \\
\hline
\end{tabular}

Table 2. Chemical composition of the raw materials used.

\begin{tabular}{lrrrrr}
\hline & \multicolumn{5}{c}{ Raw materials (wt. \%) } \\
\cline { 2 - 6 } & Kaolin & Ball clay & Quartz & K-feldspar & Basalt \\
\hline $\mathrm{SiO}_{2}$ & 47.03 & 50.67 & 97.76 & 65.37 & 36.18 \\
$\mathrm{Al}_{2} \mathrm{O}_{3}$ & 34.46 & 27.66 & 0.99 & 17.61 & 14.24 \\
$\mathrm{CaO}$ & 0.41 & 0.29 & 0.19 & 0.77 & 38.53 \\
$\mathrm{MgO}$ & 0.11 & 0.25 & 0.07 & 0.09 & 6.49 \\
$\mathrm{TiO}_{2}$ & 0.06 & 0.90 & 0.02 & 0.03 & 1.56 \\
$\mathrm{Fe}_{2} \mathrm{O}_{3}$ & 1.28 & 2.93 & 0.05 & 0.19 & 0.79 \\
$\mathrm{SO}_{3}$ & 0.08 & 0.13 & - & - & 0.69 \\
$\mathrm{~K}_{2} \mathrm{O}$ & 1.73 & 2.86 & 0.23 & 13.63 & 0.42 \\
$\mathrm{Na}_{2} \mathrm{O}$ & 0.09 & 0.15 & 0.34 & 0.90 & 0.32 \\
$\mathrm{ZrO}_{2}$ & 0.02 & - & - & 0.01 & 0.07 \\
$\mathrm{P}_{2} \mathrm{O}_{5}$ & 0.02 & 0.06 & 0.02 & 0.44 & 0.02 \\
$\mathrm{~L}_{5}$ O.I & 14.21 & 13.87 & 0.30 & 0.63 & 0.02 \\
\hline
\end{tabular}

Flexural strength at room temperature was determined via three-point bending test using a universal testing machine (Instron model 55R4502) with a span length of $20 \mathrm{~mm}$ and a crosshead speed of $0.5 \mathrm{~mm} \cdot \mathrm{min}^{-1}$. Phase analysis of raw materials and sintered samples was performed by X-ray diffraction (XRD; PANalytical, X'Pert Pro) with $40 \mathrm{kV}, 45 \mathrm{~mA}, \mathrm{CuK} \alpha$ radiation. The sample was scanned at $2 \theta$ from $10^{\circ}$ to $90^{\circ}$ with a step size of 0.04 . The microstructure of samples was characterized by scanning electron microscopy (SEM, Hitachi S-3400N).

\section{RESULTS AND DISCUSSION}

\section{Raw material characterization}

Table 2 presents the chemical compositions of the raw materials for ceramic production. The results showed that kaolin and ball clay mainly consisted of $\mathrm{SiO}_{2}$ and $\mathrm{Al}_{2} \mathrm{O}_{3}$ with a small amount of $\mathrm{CaO}, \mathrm{MgO}, \mathrm{Fe}_{2} \mathrm{O}_{3}, \mathrm{~K}_{2} \mathrm{O}$, etc. The quartz is $97.8 \%$ pure $\mathrm{SiO}_{2}$. Silica is used as a filler and stabilizer (grog) in ceramic materials [7, 15]. Feldspar as a fluxing agent mainly composed of $\mathrm{SiO}_{2}$, $\mathrm{Al}_{2} \mathrm{O}_{3}$ and $\mathrm{K}_{2} \mathrm{O}$. Basalt fibers chiefly consist of $\mathrm{SiO}_{2}$, $\mathrm{Al}_{2} \mathrm{O}_{3}$ and $\mathrm{CaO}$. Other oxides present in relatively minor amounts include $\mathrm{MgO}, \mathrm{TiO}_{2}$ and $\mathrm{Fe}_{2} \mathrm{O}_{3}$. Although basalt fibers introduce a high amount of $\mathrm{CaO}$ and $\mathrm{MgO}$ into the mixture, they are still aluminosilicates, and thus it is not unreasonable to use them as a raw material for stoneware tile production.

\section{Physical and mechanical properties}

The physical and mechanical properties, including the mineralogy and microstructure were examined to assess the effect of basalts in ceramic compositions. Figure 2 presents the physical properties of ceramic (CB-0) and ceramic-basalt samples (CB-F25, CB-Q25, $\mathrm{CB}-10$, and $\mathrm{CB}-20$ ) sintered at 1000 to $1200^{\circ} \mathrm{C}$. The linear shrinkage of ceramic (CB-0) increased with increasing firing temperature. The addition of basalt fiber could lower the shrinkage of ceramic especially with CB-10 and CB-20. In addition, the linear shrinkage of CB-10 and CB-20 significantly decreased, and the volume of samples consequently expanded at $1200^{\circ} \mathrm{C}$. This result indicated that the excessive heat treatment of samples caused an overfiring effect $[2,6]$. The presence of liquid phase is critical for densification.

Figure $2 \mathrm{~b}$ shows the bulk densities of the sintered samples after sintering at different temperatures. In case of CB-F25 and CB-Q25, the density of the ceramicbasalt samples tended to increase slowly at low sintering temperature then sharply increased after $1100^{\circ} \mathrm{C}$. On the other hand, the densification of the CB-10 and CB-20 increased with respect to the increase of sintering temperature up to $1150^{\circ} \mathrm{C}$ and then significantly decreased with further rise in temperature up to $1200^{\circ} \mathrm{C}$ 
due to overfiring of samples. This phenomenon resulted from the secondary fluxing agents such as $\mathrm{CaO}$ and $\mathrm{MgO}$ found in basalt components. These oxides may enhance or accelerate the densification by liquid phase

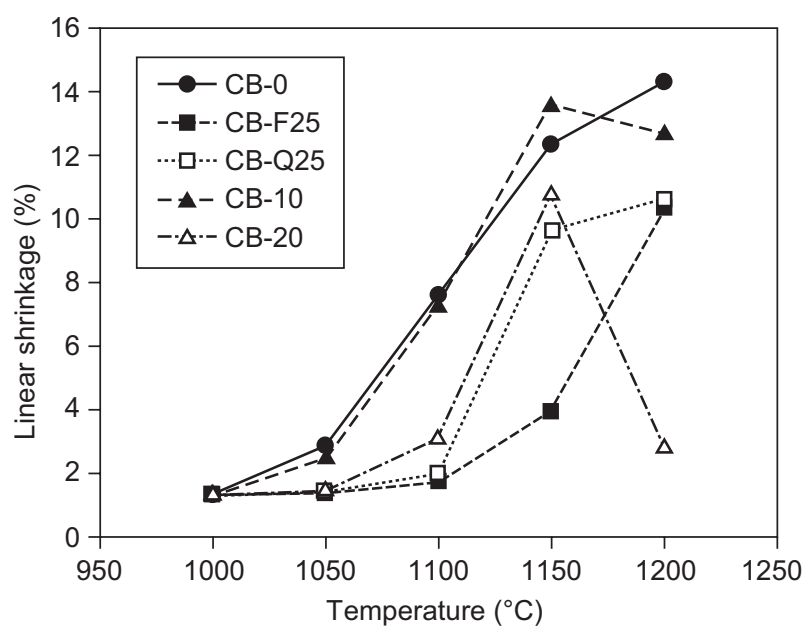

a) linear shrinkage

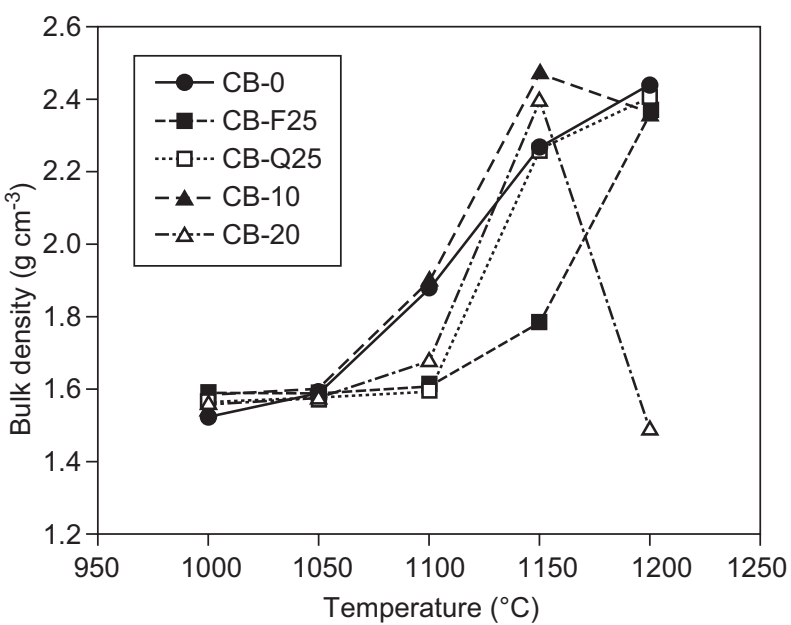

b) bulk density

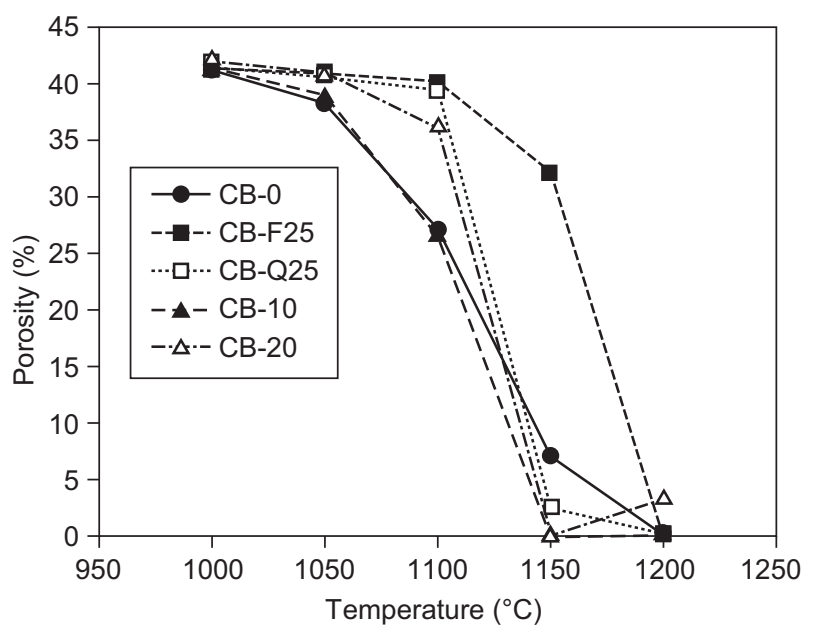

c) porosity

Figure 2. Physical properties of the samples sintered at 1000 to $1200^{\circ} \mathrm{C}$ : a) linear shrinkage, b) bulk density, and c) porosity. formation in ceramic samples. However, increasing the temperature beyond the maximum densification of samples may cause overfiring effects and consequently reduced density $[2,6]$. This is consistent with the reduced shrinkage and may be a consequence of the fact that melts with higher $\mathrm{CaO}$ and $\mathrm{MgO}$ contents do not wet the aluminosilicate surfaces. In extreme cases this may lead to swelling [16]. Comparing the basalt substitution in ceramic compositions, it was found that the partial replacement of both feldspar and quartz by basalt (CB-10, CB-20) showed superior densification than the entire replacement of feldspar or quartz by basalt (CB-F25, CB-Q25) as long as the $\mathrm{CaO}$ and $\mathrm{MgO}$ contents and the firing temperature is not too high. The CB-10 and CB-20 exhibited the maximum density of 2.48 and $2.40 \mathrm{~g} \cdot \mathrm{cm}^{-3}$ at a sintering temperature of $1150^{\circ} \mathrm{C}$. These values are comparable to the density of typical porcelain-like body, $2.3-2.5 \mathrm{~g} \cdot \mathrm{cm}^{-3}[6]$.

Figure $2 \mathrm{c}$ shows the porosity of the ceramic-basalt samples as a function of temperature, where the porosity of the samples decreased as the sintering temperature increased. The reduction of porosity was significant after sintering at $1100^{\circ} \mathrm{C}$ for all samples. The lowest porosity was $0.03-0.08 \%$ for $\mathrm{CB}-10$ and $\mathrm{CB}-20$ sintered at $1150^{\circ} \mathrm{C}$. From these results, it can be concluded that the substitution of the basalt fibers in an appropriate amount enhanced the densification of ceramic products at a lower temperature compared to ceramic samples without basalt replacement.

Figure 3 displays the flexural strength of the ceramicbasalt samples as a function of the sintering temperature. The increase in temperature had a positive effect on the strength of ceramic samples. At lower temperatures $\left(1000-1100^{\circ} \mathrm{C}\right)$, the strength values of ceramics made with basalt are higher than the basalt-free sample (CB-0). Interestingly, the strength of ceramics made with basalt sintered at $1100-1150^{\circ} \mathrm{C}(46-116 \mathrm{MPa})$ is even higher than the minimum strength values of ISO 13006 standards of ceramic tiles (35 MPa) [17].

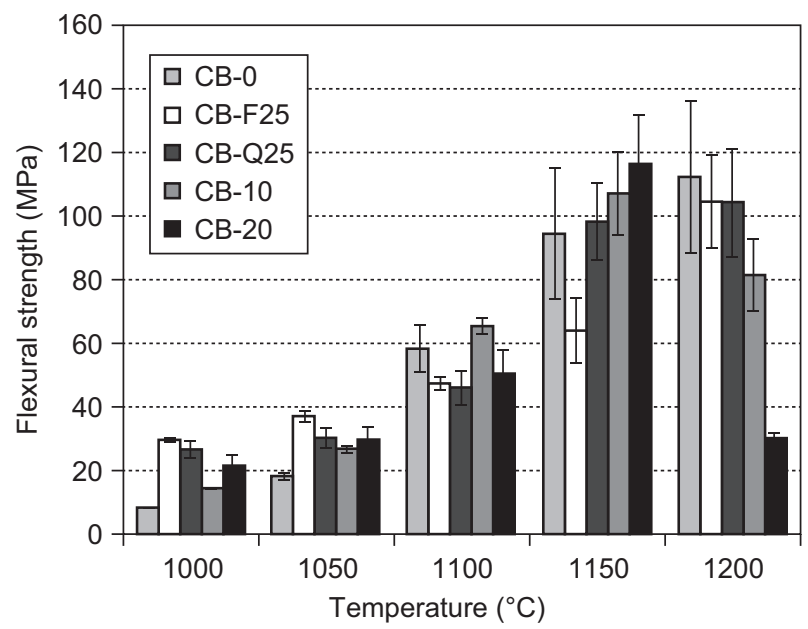

Figure 3. Flexural strength of the ceramic-basalt samples sintered at 1000 to $1200^{\circ} \mathrm{C}$. 


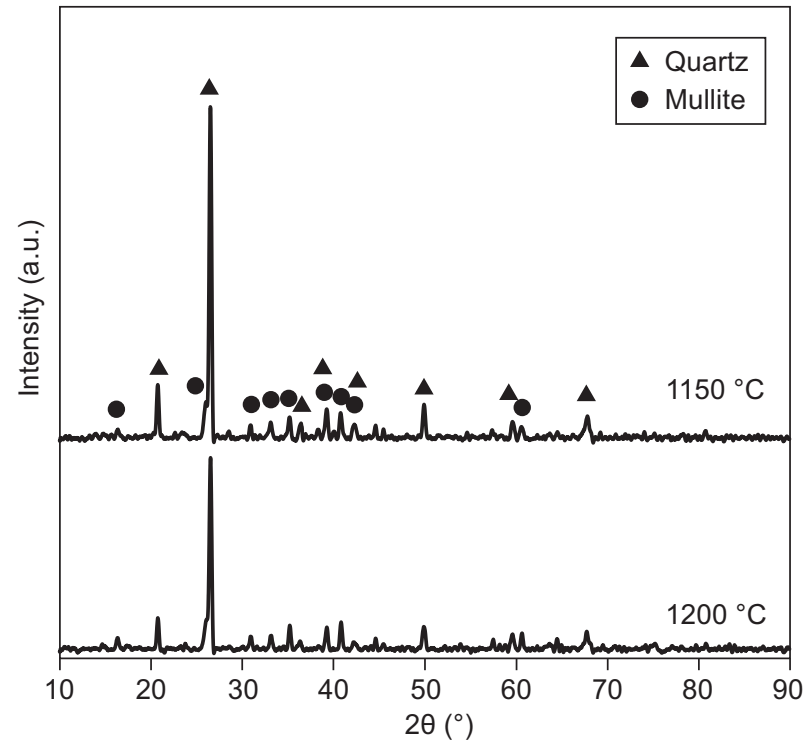

a) $\mathrm{CB}-0$

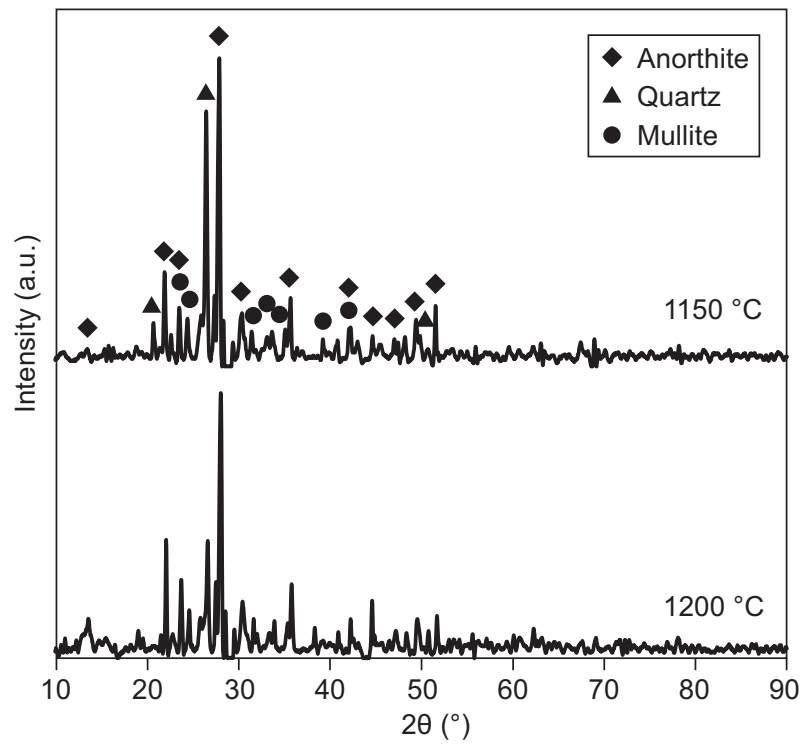

b) $\mathrm{CB}-20$

Figure 4. XRD patterns of the ceramic compositions at 1150 and $1200^{\circ} \mathrm{C}$ : a) $\mathrm{CB}-0$ and b) $\mathrm{CB}-20$.

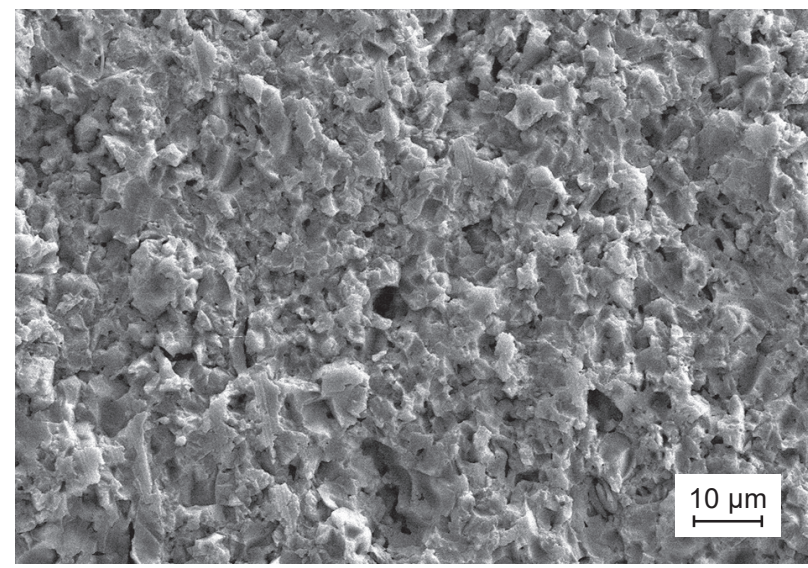

a) $\mathrm{CB}-0$

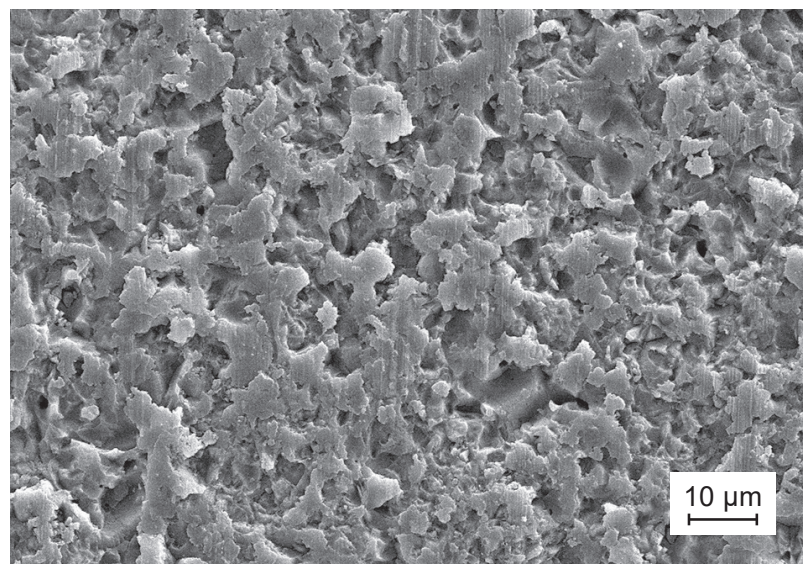

c) $\mathrm{CB}-0$

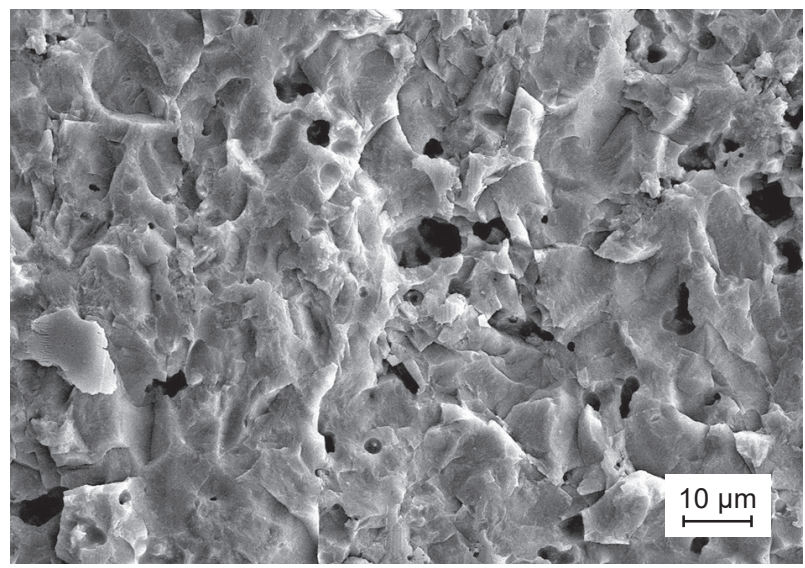

b) $\mathrm{CB}-20$ sintered at $1150^{\circ} \mathrm{C}$

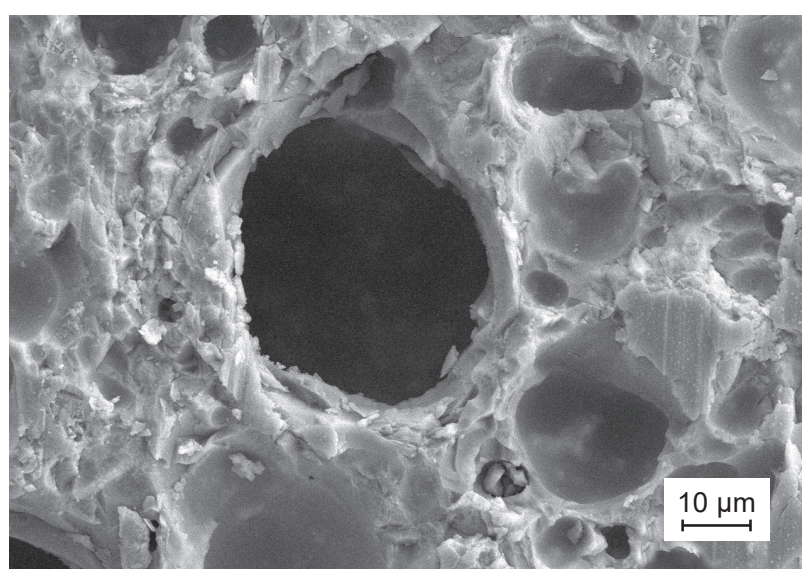

d) $\mathrm{CB}-20$ sintered at $1200^{\circ} \mathrm{C}$

Figure 5. SEM micrographs of ceramic samples with and without basalts: a) $\mathrm{CB}-0$; b) $\mathrm{CB}-20$ sintered at $1150^{\circ} \mathrm{C}$; c) $\mathrm{CB}-0$; d) $\mathrm{CB}-20$ sintered at $1200^{\circ} \mathrm{C}$. 
It was also found that the strengths of CB-20 at $1150^{\circ} \mathrm{C}$ are higher than basalt-free ceramics (CB-0) sintered at $1200^{\circ} \mathrm{C}$. The $\mathrm{CB}-20$ samples sintered at $1150^{\circ} \mathrm{C}$ exhibit the highest strength of $116 \mathrm{MPa}$. Unfortunately, the flexural strength of the CB-10 and CB-20 samples dropped rapidly at high firing temperature, $1200^{\circ} \mathrm{C}$, which corresponds well to their low bulk densities as mentioned above. Increasing the temperature beyond maximum densification of samples led to overfiring. This phenomenon is responsible for the decrease in flexural strength at high temperature [2].

\section{Phase analysis and microstructures}

Figure 4 shows the XRD patterns of the crystalline phases of CB-0 and CB-20. The basalt-free ceramic sample (CB-0) consisted of quartz $\left(\mathrm{SiO}_{2}\right)$ and mullite $\left(3 \mathrm{Al}_{2} \mathrm{O}_{3} \cdot 2 \mathrm{SiO}_{2}\right)$. The crystalline phases detected in the ceramics made with basalt (CB-20) were anorthite $\left(\mathrm{CaAl}_{2} \mathrm{Si}_{2} \mathrm{O}_{8}\right)$, quartz $\left(\mathrm{SiO}_{2}\right)$ and mullite $\left(3 \mathrm{Al}_{2} \mathrm{O}_{3} \cdot 2 \mathrm{SiO}_{2}\right)$.

Figure 5 shows SEM micrographs of ceramic samples with and without basalts (CB-0 and CB-20) sintered at 1150 and $1200^{\circ} \mathrm{C}$. In case of CB-0, the degree of densification increased with increasing temperature. In contrast, the ceramics made with basalt (CB-20) revealed more porosity at $1200^{\circ} \mathrm{C}$ due to overfiring as discussed earlier. The high porosity led to lower bulk density and flexural strength. Overall, basalt fiber can be added into clay-based ceramic compositions by replacing quartz and/or feldspar for ceramic productions in the production of tiles. The ceramic containing basalt fiber had a potential not only for enhancing the densification but also for decreasing the sintering temperature.

\section{CONCLUSIONS}

The substitution of basalt fibers (10 - 25 wt. \%) for quartz and potash feldspar in different amounts affected both physical and mechanical properties of clay-based ceramic compositions. The partial replacement of both feldspar and quartz (CB-10, CB-20) by basalt showed higher density and strength than the complete replacement of feldspar or quartz (CB-F25, CB-Q25) by basalt. The substitution of the basalt fibers in appropriate amounts could enhance the densification and reduce sintering temperature of clay-based ceramics. In this study, ceramics made with basalt can be successfully sintered at a temperature of $1150^{\circ} \mathrm{C}$. CB-20 exhibited the highest density and strength $\left(2.40 \mathrm{~g} \cdot \mathrm{cm}^{-3}\right.$ and $116 \mathrm{MPa}$, respectively). Therefore, it is possible to utilize basalt fibers as an alternative raw material in clay compositions for ceramic productions such as tiles.

\section{Acknowledgements}

This research was financially supported by the National Metal and Materials Technology Center, Thailand (Project No. MT-B-55-CER-07-293-I).

\section{REFERENCES}

1. Galos K. (2011): Composition and ceramic properties of ball clays for porcelain stoneware tiles manufacture in Poland. Applied clay science, 51(1), 74-85. doi:10.1016/j.clay.2010.11. 004

2. Zanelli C., Raimondo M., Guarini G., Dondi M. (2011): The vitreous phase of porcelain stoneware: composition, evolution during sintering and physical properties. Journal of Non-Crystalline Solids, 357(16), 3251-3260. doi:10.1016/j. jnoncrysol.2011.05.020

3. Torres P., Fernandes H.R., Agathopoulos S., Tulyaganov D.U., Ferreira J.M.F. (2004): Incorporation of granite cutting sludge in industrial porcelain tile formulations. Journal of the European Ceramic Society, 24(10), 3177-3185. doi:10.1016/j. jeurceramsoc.2003.10.039

4. Menezes R.R., Ferreira H.S., Neves G.A., Lira H.d.L., Ferreira H.C. (2005): Use of granite sawing wastes in the production of ceramic bricks and tiles. Journal of the European Ceramic Society, 25(7), 1149-1158. doi:10.1016/j.jeurceramsoc.2004. 04.020

5. Mukhopadhyay T.K., Ghosh S., Ghatak S., Maiti H.S. (2006): Effect of pyrophyllite on vitrification and on physical properties of triaxial porcelain. Ceramics international, 32(8), 871-876. doi:10.1016/j.ceramint.2005.07.002

6. Serra M.F., Conconi M.S., Suarez G., Aglietti E.F., Rendtorff N.M. (2015): Volcanic ash as flux in clay based triaxial ceramic materials, effect of the firing temperature in phases and mechanical properties. Ceramics International, 41(5), 61696177. doi:10.1016/j.ceramint.2014.12.123

7. Firat F.A., Erenk E., Yilmaz S. (2012): Effect of substitution of basalt for quartz in triaxial porcelain. Journal of Ceramic Processing Research, 13(6), 756-761.

8. Poznyak A.I., Levitskii I.A., Barantseva S.E. (2012): Basaltic and granitic rocks as components of ceramic mixes for interior wall tiles. Glass and Ceramics, 69, 262-266. doi:10.1007/ s10717-012-9458-5

9. Sathiyakumar M., Gnanam F.D. (2003): Role of wollastonite additive on density, microstructure and mechanical properties of alumina. Ceramics international, 29(8), 869-873. doi:10.1016/S0272-8842(03)00029-4

10. Ke S., Cheng X., Wang Y., Wang Q., Wang H. (2013): Dolomite, wollastonite and calcite as different $\mathrm{CaO}$ sources in anorthitebased porcelain. Ceramics International, 39(5), 4953-4960. doi:10.1016/j.ceramint.2012.11.091

11. Turkmen O., Kucuk A., Akpinar S. (2015): Effect of wollastonite addition on sintering of hard porcelain. Ceramics International, 41(4), 5505-5512. doi:10.1016/j.ceramint.2014.12.126

12. Jiang C., Fan K., Wu F., Chen D. (2014): Experimental study on the mechanical properties and microstructure of chopped basalt fibre reinforced concrete. Materials \& Design, 58, 187-193. doi:10.1016/j.matdes.2014.01.056

13. King M.F.L., Srinivasan V., Purushothaman T. (2014): Basalt Fiber: An Ancient Material for Innovative and Modern Applicationc. Middle-East Journal of Scientific Research, 22, 308-312. doi:10.5829/idosi.mejsr.2014.22.02.21872

14. Fiore V., Scalici T., Di Bella G., Valenza A. (2015): A review on basalt fibre and its composites. Composites Part B: Engineering, 74, 74-94. doi:10.1016/j.compositesb.2014.12.034

15. Pérez J.M., Rincón J.M., Romero M. (2012): Effect of moulding pressure on microstructure and technological properties of porcelain stoneware. Ceramics International, 38(1), 317-325. doi:10.1016/j.ceramint.2011.07.009

16. Rahaman, M.N. (2003). Ceramic Processing and Sintering. $2^{\text {nd }}$ ed., p. 620-687, Marcel Dekker, Inc., New York.

17. Ceramic Tiles - Definitions, Classification, Characteristics and Marking. International Organization for Standardization, ISO 13006, 1998. 